\title{
Applied Entomology and Zoology Vol. 45, No. 1 内容紹介
}

輸入マルハナバチの生態リスク評価特集の導入として：日 本におけるセイヨウオオマルハナバチの有益昆虫および侵 略的外来種としての地位 五箇公一 (国立環境研) ……1 1 セイヨウオオマルハナバチは, 1991 年にハウストマトの受粉用 昆虫として日本に導入が開始された。多くの生態学者が, 本種の 生物学的侵入の恐れを指摘し，1996 年には北海道において野生巣 が発見されたことにより，定着が確定的となった，環境省は，外 来種から日本の生態系を保全することを目的として，2005 年に外 来生物法を施行した。 そして保全生態学者と農業関係者の間で, 本種を法的に規制するか否かで論争が起きることとなった。この 問題を科学的に解決することを目的として，七イヨウオオマルハ ナバチの生態影響を明らかにするとともに，本種の野生化を防止 する技術の開発に関する研究プロジェクトが開始された。年の研 究成果に基づき, セイヨウオオマルハナバチは在来の生態系に対 して侵略的であり，法的規制を受けるべき外来種であると決定さ れた。ただし，農業利用に限って，逃亡防止技術が施された施設 内での本種の使用を許可することも同時に決定された。 セイヨウ オオマルハナバチの法的管理は, 生物多梯性と農業の両立を目指 した革新的な試みと言ってよい。

\section{西ヨーロッパおよび北米における外来マルハナバチの影響}

Dave Goulson（University of Stirling，イギリス）……....7 7 マルハナバチ類の生息域外への人為移送の開始は，100 年以上 前に遡る。午の後, 1980 年代にコロニーの大量飼育技術が発達 し，マルハナバチ類は八ウストマトを中心とした施設栽培作物の 花粉媒介用昆虫として，世界各地に移送されるようになった。そ して，現在，世界中でも最も頻繁に移送されているのが南東ヨー ロッパ原産のセイヨウオオマルハナバチ dalmatinus 亜種である. 北米では，七イヨウオオマルハナバチの輸入が禁止されており， 代わりにBombus impatiens が主に利用されている．七イヨウオオ マルハナバチ dalmatinus 亜種の移送は, イギリスやアイルランド 固有要種のセイヨウオオマルハナバチ audax 亜種のようなヨーロッ パ内の他带種に対して脅威となっている。しかし, dalmatinus 带 種が生息域外に定着しているのか, 在来亜種と交雑しているのか はっきりとしたデータはない，恐らく，より深刻なリスクは，寄 生生物の持ち込みであらうと考元られる。実際に北米の在来マル 八ナバチの数種の急速な減少がヨーロッパからの病原体の持ち込 みによって引き起こされたという状沉証拠もある。、ルハナバチ の商品コロニーが限られた地域て飼育・生産されているとしても， 高密度で飼育されているという状態は, 八ウス利用のコロニーを 寄生生物のリザーバーとして機能させることとなる。 マルハナバ チの移送にあたっては, 厳重な検疫体制が必要であり, 在来種利 用への転換も考慮すべきと考えられる。
花粉媒介昆虫の群集構造の変化が送粉生態系に及ぼす影響 の理論解析 James E. CRESSWELL (University of Exeter, イ ギリス)

外来種とは, ある群集にとって予想外の存在となる。従って, 新たに侵入した外来種によってもたらされた在来生物群集への影 響を修復する手法の必要性に関して, 素早い判断が求められる。 ここに, 私は, 外来ポリネーターが送粉生態系にもたらす影響を 予測するための理論モデルの数々の開発を試みた。これらのモデ ルは, 外来ポリネーターの存在が, 植物の繁殖や, 在来ポリネー ターの行動に及ぼす影響を解析してくれる。モデルはシンプルで あるが，㶢れらの解は実際のデータと照らし合わせて再現性があ る.これらモデルは, 生態学者や保全学者が外来ポリネーターの 影響ポテンシャルを予測する上での初めての近似法を提供するも のである。これらのモデルから得られた結果は, 予防原則に則っ た外来種管理に適用すべきと考えられる。

日本におけるセイヨウオオマルハナバチ（Bombus terrestris (L.)）の侵入と分布拡大の現状 横山 潤 ${ }^{1}$. 井上真紀 ${ }^{2}$ ( ${ }^{1}$ 山形大理生物, ${ }^{2}$ 国立環境研) …………………..... 21

セイヨウオオマルハナバチは日本を含む世界各地で, 農業用の 送粉昆虫として利用されている。 そしていくつかの地域では，七 イヨウオオマルハナバチの野生化が報告されて打り, 在来生態系 への影響が懸念されている。本論文では, 日本国内での本種の侵 入と分布拡大の現状を概観し, 特に今後の自然植生一の分布拡大 の可能性について詳述した。これまでの知見から, 日本では 1996 年に北海道で野生化が報告されて以降，道内での分布範囲は拡大 の一途をたどっている．セイヨウオオマルハナバチは原産地同様 に, 北海道でも農耕地のような人為的な改変の進んだ環境に侵入 している.しかし，近年セイヨウオオマルハナバチが確認された 地域には, 海岸草地や高山草原のように自然度の高い環境も含ま れている. 北海道内の保全上重要な自然環境は, 現在セイヨウオ オマルハナバチの侵入にさらされており，継続的なモニタリング 調査が必要である.

外来種セイヨウオオマルハナバチと在来マルハナバチにお ける花資源と営巣場所をめぐる競争 井上真紀（国立環境 研）・横山 潤（山形大理生物）

外来種セイヨウオオマルハナバチは，近年日本に打いて野生化 し，優占種となっている。本レビューでは，まず日本拉よび海外 に打けるセイヨウオオマルハナバチの在来八チ類への影響に関す る先行研究を紹介する.さらに, ニッチ重複打よび資源制限, お よびセイヨウオオマルハナバチの繁殖能力について検討し, 競争 排除の可能性を評価した我々の研究を紹介する. 先行研究では, 在来八千類との高いニッチ重複や在来八チ類の減少について報告 されて打り，競争排除が起きている可能性が示されている。しか 
し，在来種に対する競争排除を介したセイヨウオオマルハナバチ の生態影響については確たる証拠は示されていない. 我々の研究 から, 営巣場所が限られた資源であり, 営巣場所が重複している 在来種エゾオオマルハナバチとエゾトラマルハナバチが競争排除 を介した影響を受けている可能性が示された。また，セイヨウオ オマルハナバチの野生巣では, 平均 90.2 個体の女王を生産してお り，高い繁殖能力を有することが明らかとなった。野外調査の結 果, セイヨウオオマルハナバチの増加に伴い, エゾオオマルハナ バチ扎よびエゾトラマルハナバチの個体数減少が示された。この ことから，セイヨウオオマルハナバチ野生化による在来種の競争 排除が起きていることが明らかになった。

\section{外来ハナバチ類が在来植物と送粉者の相互作用に及ぼす影} 響：特に植物の繁殖に注目した総説 堂直いくみ ${ }^{1} \cdot$ 横山 潤 2 ( ${ }^{1}$ 神戸大院人間発達環境, ${ }^{2}$ 山形大院理生物) ……3 37

外来送粉昆虫は，植物と送粉者の密接な関係に影響を与えてい る。本論文では, 外来のミッバチとマルハナバチによる在来植物 の種子繁殖への影響について, これまでの研究を概観した。外来 送粉昆虫の影響は, 送粉様式の違いや送粉成功の成分（訪花頻 度・訪花あたりの花粉運搬効率, 花粉制限) によっても変動が大 きかった，鳥媒花植物では，外来ミッバチによる訪花があっても， 鳥による受粉が十分に行われているため，外来ミッバチによる影 響は比較的少ない，八千媒花植物では，外来ミッバチによる影響 が広がっている傾向がある。しかし，多くの研究は外来ミッバチ が存在しない対照区がないため, 艺の植物の種子繁殖への影響を 明確に提示できていない。、ルハナバチ媒花植物では, 外来マル 八ナバチと在来種は同属で近縁なので, 送粉機構も似ている。そ のため, 外来マルハナバチは在来マルハナバチと競合したり, ま たは取って代わることによって，在来植物に強い影響を与えてい る. 多くの研究から, 在来種と外来種の形態的 - 生態的・行動的 な類似は, 競合の強さや, 植物繁殖への影響を予測する上で重要 であることがわかった．外来八ナバチ種の影響は，1）花と外来種 の形態的対応がないため, 訪花あたりの花粉運搬効率が下がる. 2）在来種と外来種の生態的特性が似ているため，八千の花資源を めぐる競合や在来種の排除が増える．3）在来種の訪花頻度や送粉 効率の変化は, 外来種の行動形質によって引き起こされる（盜蜜 や柱頭についていた花粉を集めてしまうなど)．外来送粉者の影響 を量的に評価するためには，在来植物が花粉制限を受けているか 明らかにすることが重要であり, 花粉制限を実証するためには, 外来種のいない対照区との比較が必要である。これは，外来種に よる影響のメカニズムを明らかにするために有効である.

導入されたセイヨウオオマルハナバチからの日本在来種に 対する繁殖摫乱リスク 土田浩治 ${ }^{1}$. 今藤 - 伊藤夏子 ${ }^{2}$. 井上真紀 ${ }^{2}$. 五箇公一 ${ }^{2}\left({ }^{1}\right.$ 岐阜大応用生物, ${ }^{2}$ 国立環境 研)

セイヨウオオマルハナバチは, 効果的な送粉者であるばかりで なく, 原産地の外では侵略的な種である可能性を持っている。実 験室内では, 在来種であるエゾオオマルハナバチやクロマルハナ
バチとセイヨウオオマルハナバチの種間交雑は発育不能な雑種形 成を引き起こす，さらに，野外の約 $30 \%$ のエゾオオマルハナバチ とオオマルハナバチの女王バチはセイヨウオオマルハナバチのオ スと交雑すると推定されており，導入種との交雑を通して在来種 の遺伝的劣化が起きていることが示唆されている。ここでは, 種 間の生殖隔離機構を簡潔に要約し, 種間交尾による日本在来のマ ルハナバチ種の繁殖に対するセイヨウオオマルハナバチの負の影 響について議論する。

半倍数性個体群における家族数推定法 徳永幸彦（筑波大 生命共存科学) - 小久保望 (エム・アール・アイリサー チアソシエイッ(株) ) 59

近年日本国内に侵入しつつあるセイヨウオオマルハナバチの定 着コロニー数を推定することは, この侵入生物を駆除をする上で, 避けては通れない課題である。ママルハナバチの巣を野外で発見す ることは極めて難しいため, 採䬣個体の遺伝的多様性から, 炎れ らの個体が由来する巣数を推定することが必要となる。対立遺伝 子の組み合わせの多様性から家族構造を再構築することは理論的 にはNP困難な問題ではあるが，可能な組み合わせを全計算をし なくても済む方法が幾つか考案されてきている，穴の中でも最尤 法に基づく方法が多く用いられてきてはいるが, 対立遺伝子頻度 の推定精度を上げるために, 推定対象個体群からのサンプルサイ ズが比較的大きくなくてはいけないという制約がある。爷れとは 別に，個体同士の遺伝的距離を算出してクラスターを作り，家族 構成を再構築する方法も提案されているが，現実の問題に当ては めて推定する際に，いろいろ利点と欠点があることが議論されて いる. 著者らは対象を半倍数性の個体群に限定し, 新たな家族構 成推定法（Shared Loci Correspondence Analysis: SLCA）を考案し た。 SLCA は 2 対比較する個体同士が共有する遺伝子座の数に よって, 個体間の遺伝的距離を算出する。そして, 個体同士の遺 伝的似かより度に基づく距離行列を対応分析にかけることによっ て，父親を共有する家族構造，すなわち巣のメンバー構成を再構 築する. SLCA は実際, 非常に小さなサンプルサイズの野外のマ ルハナバチの巣の数を，正確に推定することができた，著者らは さらに SLCA の推定精度を向上させた mSLCA（modified SLCA） を考案した。mSLCA は遺伝子座数と各遺伝子座における対立遺 伝子数がそれぞれ 8 以上もあれば，かなり偏ったサンプルでも正 確に家族構造を再構築することができた。 mSLCAの今後の展開 についても議論する.

日本の外来生物法 水谷知生（環境省自然環境局）・五䇢 公一 (国立環境研) ………………………………....6 65

日本政府は，2004 年に侵略的外来種による生態系への被害の防 止を目的として外来生物法を制定した。法律では, 生態系, 人の 健康, 農林水産業への被害を生じさせる, あるいはその打机の ある外来種を「特定外来生物」とする。「特定外来生物」に指定 された外来種は, 主務大臣の許可を受けることなく飼養, 栽培, 保管，運搬をすることが禁止されるといった様々な規制がかけら れる。この法律は日本での，また世界的にみても，生物多様性保 
全に関する革新的な取り組みと言える。しかし，この法律の施行 上の課題は多い. 特に特定外来生物セイヨウオオマルハナバチに 関しては, 生物多様性の保全と農業生産との間の厳しいジレンマ を解決する必要がある，日本における外来種管理の困難さの根底 には，日本経済の世界的地位という問題がある。

外来種セイヨウオオマルハナバチと在来種における採饋効 率の比較 井上真紀 (国立環境研) - 牧野崇司（筑波大生 命環境）・横山 潤 (山形大理生物) - 酒井聡樹（東北大 院生命科学)

71

外来種セイヨウオオマルハナバチは近年日本に野生化し，在来 マルハナバチ個体群の減少を引き起こしていると考えられている. そこで, 本研究ではセイヨウオオマルハナバチと在来種クロマル ハナバチの採餌能力の比較実験を行った。6日間の実験の結果， セイヨウオオマルハナバチの体サイズがクロマルハナバチよりも 有意に小さいにもかかわらず，採䭒量に違いはみられなかった。 しかし，セイヨウオオマルハナバチは，単位時間当たり，体重当 たりの䬣持ち帰り量が有意に多かった。セイヨウオオマルハナバ チのワーカーの口吻長が実験に用いたブルーサルビアの花のサイ ズと一致していたため, より効率的であったと考えられる。 セイ ヨウオオマルハナバチの侵入地では, すでに優占種となっている 地域も多い。このことから, 資源が少ない場合, より優れた採餌 ワーカーを有するセイヨウオオマルハナバチが資源の搾取によっ て在来種に悪影響を及ぼすことが推測された。

クロマルハナバチのミトコンドリア DNA における地理的 変異 所 諭史 (茨城大教育) ·米田昌浩 - 国武陽子 - 五 箇公一(国立環境研) 77

日本在来のマルハナバチの 1 種であるクロマルハナバチは, 授 粉用昆虫として, 近年, 商品化された。商品クロマルハナバチの 利用拡大がもたらす局所個体群における遺伝的覮乱のリスクを評 価するため，我々は日本，中国そして韓国の様々な地域における クロマルハナバチを採集し，ミトコンドリア DNA-CO1 領域の塩 基配列変異を解析した。その結果，15 のハプロタイプを検出した が，それらのなかで日本と大陸の個体群間で共有されているタイ プは一つもなかった。また DNA 系統解析の結果から，日本の個 体群が大陸の個体群から遺伝的に分化していることが示された. さらに，日本に打ける $\mathrm{CO} 1$ ハプロタイプの頻度分布は，地理的な パターンを示し，日本の個体群間に抢いても遺伝的分化の存在を 示唆した。これらの結果は, クロマルハナバチの商品コロニーが 流通するにあたっては, 野生クロマルハナバチ個体群の遺伝的固 有性を考慮しなければならないことを示している。
チャタテムシ：世界の食糧の安全確保にとっての新しい危 険因子 Muhammad Shoaib AHMEDANI ${ }^{1}$ - Naz ShaGUfta ${ }^{2}$. Muhammad ASLAM $^{1}$ ・ Sayyed Ali HuSSAIN ${ }^{3}$ ( ${ }^{1}$ アリッド農業 大学昆虫学部, 2 パキスタン農業省農業部, 3 サセックス大 学生命科学部，パキスタン) ……………............. 89

貯穀害虫による収穫後の被害は世界の食糧の安全確保にとって 大きな脅威になりつつある、貯穀害虫のなかで, チャタテムシは, それらによる被害の明確な証拠がなかったため過去に打いては無 視された。それらの経済的重要性が, ここ数年世界中の多くの研 究者によって認識されてきた。 公表された報告は, チャタテムシ が世界の食糧の安全確保にとって新しい危険因子として認識され るべきであることを示す。米国, 豪州, 英国, ブラジル, インド ネシア, 中国, インド, パキスタンでチャタテムシが貯穀に被害 をもたらしていることが分かっている．約 16 種のチャタテムシが 同定され，貯穀害虫として知られている。チャタテムシは一般に， カビに污染された穀粒を好むが，力ビに污染されていなくても， 欠けたあるいはひびが入った穀粒の柔らかい内肧乳に食い入るこ とはできる。チャタテムシの摂食による経済的損害は, 污染の程 度と虫の密度とともに増える，チャタテムシは人間の健康を害す るという報告もある。チャタテムシの経済的重要性を鑑み, チャ タテムシの系統, 分布, 生態, 防除, 被害状況の概要がこの総説 で述べられる。

ポリネーター, 侵略的外来種, そして害虫としてのセイヨ ウオオマルハナバチ：商業利用目的での導入拡大がもたら す問題の評価 Amots DAFNI（Haifa Univ., イスラエル)・ Peter Kevan (Unv. of Guelph, カナダ) • Caroline L. Gross (Unv. of New England，オーストラリア）・五箇公一（国立 環境研) 101

セイヨウオオマルハナバチ Bombus terrestris は温帯ユーラシアに 生息しており，1800 年代からニュージーランドをはじめとして広 く世界中に移送されてきた。1980 年代に入って，ヨーロッパにお いてマルハナバチの人工飼育法が確立し，トマトをはじめとする 農業作物の送粉昆虫（ポリネーター）として商品化されたことに より，セイヨウオオマルハナバチの移送はいっそう拡大した．商 業用コロニーの輸入が開始されてから間もなく，本種は，特に日 本やイスラエルに打いて, 侵略的外来種であり, 地域固有の生態 系を擋乱する恐れがあると考えられた。セイヨウオオマルハナバ チは施設栽培におけるポリネーターとして優れた特性を持つ。ま ず，人為的環境に対して高い適応性をもち，大きな巣を作る能力 があり，様々な作物の花粉媒介ができて，高い結実率をもたらす ことができ，しかもハウス栽培環境でも野外環境でも活動が可能 である。一方，本種は侵略的外来種としての特性も併せ持つ。ま ず，移動能力が高く，巣の創設が早い時期から行われ，様々な生 息環境と気候条件に適応できて，訪花する植物の幅も広く，低温 にも強い。移送先の新天地では，天敵もいないうえに， 1 年間に 2 化の発生をすることもできる。ささに，商品用マルハナバチは より多くの繁殖虫を生産するため, 野生化した場合, 地域の在来 八ナバチ個体群と競合して，駆逐してしまう可能性がある。これ 
までに報告されているセイヨウオオマルハナバチの自然生態系に 対する影響としては, 地域のハナバチ群集への悪影響, 在来のマ ルハナバチ類との巣場所を巡る競合打よび遺伝的浸透や，寄生生 物の持ち込み, 在来植物の繁殖阻害が挙げられる。 セイヨウオオ マルハナバチの地域レベル执よび地球レベルでの侵略を抑制する ための方策について議論したい.

イモゾウムシにおける Nardonella 属共生細菌の発見 細川 貴弘・深津武馬（産総研） 115

サツマイモの害虫であるイモゾウムシに体内共生細菌が存在す るかどうかを調べた。雌成虫の腹部から抽出した DNA サンプルに ついて細菌の $16 \mathrm{~S}$ rRNA および groEL 遺伝子を PCR で増幅し, ク ローニング・配列決定・分子系統解析を抢こなったところ $\gamma$ プロ テオバクテリア亜綱 Nardonella 属に属する共生細菌が存在するこ とが明らかとなったＩn situ八イブリダイゼーション法を用いた 組織観察によって, この共生細菌は雌成虫の卵巣に存在すること が示された. Nardonella 属の共生細菌はこれまでオサゾウムシ科 とアナアキゾウムシ带科での久報告されて打り，本研究はクチカ クシゾウムシ带科に打ける Nardonella 属共生細菌を初めて報告す るものである. 共生細菌の生物機能およびイモゾウムシ防除にお ける利用の可能性について考察した。

アジア型マイマイガ（AGM）雌成虫の夜間の飛翔行動 岩 泉 連・荒川賢良（横浜植物防疫所）・小汐千春（鳴門教 育大）

日本産マイマイガ雌成虫の行動，特に夜間の飛翔による移動行 動を，温室内に設置した網室を用いて，5月から８月の自然日長 条件下（横浜市）で観察した。処女雌・既交尾雌とも, 日没後 1-2 時間に相当する 19:00 から 21:00の間に飛翔行動がみられた。 処女雌は飛翔後もフェロモンを放出するコーリング行動を続け， 夜間に交尾を行う個体も観察された。夜間や翌日の昼間に交尾で きなかった処女雌では，翌日以降も夕方の飛翔行動が観察された。 既交尾雌は通常飛翔を伴う移動行動を行った後に産卵を開始した が，夜間に交尾した䧳はしばしば移動せずそのまま産卵を開始し た。産卵開始後の飛翔行動はみられなかった。処女雌 1 個体の飛 翔行動を動画撮影して飛翔速度を計算したところ, 分速 $21.3 \mathrm{~m}$ と 推定された。また，平均飛翔時間は処女雌，既交尾雌とも約 10 分 で, 飛翔距離は平均約 $200 \mathrm{~m}$, 最大約 $750 \mathrm{~m}$ と推定された。この ようなマイマイガ雌成虫の飛翔行動や夜間の交尾行動は, 今後, アジア型マイマイガの防除法を確立する際に考慮する必要がある と思われる。

ケブカアカチャコガネの水溶性アルコール性フェロモンの 空気中からの捕集および定量法 安居拓恵 ${ }^{1}$. 若村定

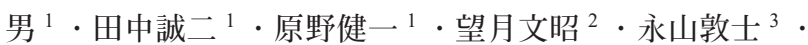
外間康洋 ${ }^{3}$ - 新垣則雄 ${ }^{3}\left({ }^{1}\right.$ 農業生物資源研, ${ }^{2}$ 信越化学, 3 沖縄県農業研究セ)

ケブカアカチャコガネメスが放出する性フェロモン量を知るた めにフェロモン物質の捕集方法を開発した。性フェロモン物質で
ある水溶性の 2-ブタノールはじめ関連の 2-プロパノールおよび エタノールを，いったん水でトラップし，SPME 法で抽出したの ち GC-MS 分析することにより定性・定量分析が可能となった。野 外から持ち帰ったメス成虫をビーカーに入れ，放出されたこれら の物質を分析したところ，1回のコーリングで $2-$ ブタノールを 100 $\mathrm{ng}$ 以上，2-プロパノールを $50 \mathrm{ng}$ 程度，エタノールを $500 \mathrm{ng}$ 程度 放出していることが明らかとなった。室内 2 回目のコーリング以 降は 2-ブタノールの放出量は激減し, その後も回復しなかった。 オスからも同程度の 2-プロパノールとエタノールが検出された が，2-ブタノールは痕跡量であった。

侵入害虫キムネクロナガハムシは八重山諸島の土着ヤシを 加害する 高須啓志 (九州大) - 高野俊一郎（九州大院生 物資源環境）・小西和彦 (北海道農業研究セ) ・ 中村 達 (国際農林水産業研究セ) …………………………1 137

キムネクロナガ八ムシはインドネシア，パプアニューギニア原 産だと考えられているが，アジア，オーストラリア，太平洋諸島 などの地域に定着し, ココヤシの葉に大きな被害を出している. 本種は 1980 年代に八重山諸島のココヤシ上で確認されたが，それ 以降, 本種が八重山諸島に定着しているのか, また土着種のヤエ ヤマヤシへの被害がないのか分かっていない. 本種によるヤエヤ マヤシへの被害の程度を明らかにするために 2007 年から 2009 年 にかけて野外調査を行った。キムネクロナガ八ムシは, 石垣島, 西表島および小浜島のほとんどの苗木栽培場所や街路樹のヤエヤ マヤシ苗木を加害していたが, 天然記念物に指定されているヤエ ヤマヤシ自生林では大きな被害は確認されなかった。2008 年 11 月と 2009 年 5 月にはすべての発育ステージが存在した。本研究 は，ココヤシが稀である八重山諸島においてキムネクロナガ八ム シは多く存在し, 主要な寄主としてヤエヤマヤシを利用している ことを初めて記載するものである.

カイコ Bombyx mori（Lepidoptera: Bombycidae）における 霊菌 Serratia marcescens による敗血症に対するキトサンの 効果 Bin LI - Ting SU • Xiaoling CHEN • Baoping LiU • Bo ZhU • Yuan FAnG - Wen QIU • Guanlin XIE（浙江大学 バイオテクノロジー研究所, 中国） 145

キトサンは抗菌活性を持つことからヒトの医療現場で利用され てきている。本研究では, カイコの細菌性敗血症を防除する目的 で，カイコに病原性のセラチア属菌 Serratia marcescens に対する キトサンの抗菌活性を調査した. 2 系統の S. marcescens, ZJS0801 とZJS0802, を用いて, 種々のキトサン濃度 $(0.01,0.05,0.1$ $\mathrm{mg} / \mathrm{ml}$ ) による抗菌活性を調査した結果, ZJS0801 系統はキトサン の濃度に依存して死滅したのに対し，ZJS0802 系統は $0.01 \mathrm{mg} / \mathrm{ml}$ で $98.9 \%$ が死滅した。 また, キトサン $(0.1 \mathrm{mg} / \mathrm{ml})$ の抗菌活性は, いずれの系統に対しても処理時間にともなって増加した，ZJS0801 系統とキトサンを混合してカイコに接種した結果, カイコの致死 率はZJJ0801 系統のみを接種したものと比較して著しく低下した。 さらに，キトサン処理したクワを与えたカイコの ZJS0801 系統に よる致死率は, キトサン処理をしていないクワを与えたカイコと 
比較して著しく低下した。 以上の結果から，キトサンはカイコの 細菌性敗血症に対して防除効果のあることが示された。

\section{カイコ卵抽出物はカイコ初期胚の初代培養において細胞の} 遊走と増殖を促進する 秋月 岳（農業生物資源研）‥1 153

牛胎児血清（FBS）は, 多くの昆虫細胞系を培養する際に使わ れる栄養源であり, 細胞増殖を促進する生理活性物質の供給源で もある。しかしながら，FBSに含まれる増殖促進因子は昆虫が産 出するものと同一ではないことから, 昆虫細胞の FBS に対する反 応は内在性成長因子に対する反応と異なる可能性がある。本研究 では, カイコ肧組織断片の初代培養に扔いて, この断片がカイコ 卵抽出物と FBS に対して異なった反応を示すかどうかを観察した。 その結果カイコ卵抽出物は肧組織断片の初代培養において FBS よ り強力に細胞の移動と成長を促進することが観察された。このこ とは, 初期発生段階のカイコ卵抽出物が強く細胞遊走と成長を促 進する分子を含むことを示唆している。また卵抽出物を用いるこ とで，新しい細胞系を確立することに要する時間を短縮すること も可能である.

人工飼料によるツゲノメイガの飼育 河津 圭（東工大）・ 中村 傑・足達太郎 (東農大) ………………..... 163

ツゲの害虫であるッゲノメイガを幼虫期間を通じて人工飼料で 飼育する方法を検討した。クサツゲの乾燥粉末と市販の基礎飼料 （インセクタ F-II，日本農産工業（株）製）を $30: 70$ の割合で配合 した人工飼料を調製し，孵化直後の幼虫に与えると，約 $70 \%$ の個 体が蛹まで成育した。寄主植物乾燥粉末を混合した人工飼料での 幼虫期間, 蛹期間, 蛹重, 蛹化率, 羽化率は, 寄主植物葉 (クサ ツゲ）だけで飼育した場合とほぼ同じであった。また，各飼育に より得られた雌成虫の産卵数, 産卵前期間, 卵豙化率も有意な差が なかった。一方, 寄主植物葉乾燥粉末を配合せずに, 市販の人工 飼料だけで孵化幼虫を飼育した場合，蛹まで成育した個体はいな かった。寄主植物乾燥粉末を混合した人工飼料による本飼育方法 は, ツゲノメイガの年間を通して安定した飼育を可能にするもの である。

ツゲノメイガの雄ガの性フェロモン反応性の日周変動に及 ぼす光周期の影響 河津 圭（東工大）・中村 傑（東農 大）・本田 洋（筑波大）・足達太郎（東農大）………169

ツゲノメイガの雄ガの性フェロモンに対する反応性に影響する 光周期の効果を調べた。 $16 \mathrm{~L} 8 \mathrm{D}$ の明暗周期から雄のガを全暗, 全 明条件に移すと， $16 \mathrm{~L} 8 \mathrm{D}$ の明暗周期で暗期に相当する時間帯に反 応性を示したことから，ツゲノメイガの雄の性フェロモンに対す る反応性にはサーカディアンリズムが存在することがわかった. 3 種類の明暗周期下で暗期に打ける雄の反応性を調べたところ，い ずれの明暗周期でも消灯直後から反応性がみられ，消灯 2 時間後 に最大レベルに達し, 以後暗期終了まで維持された。さらに， $16 \mathrm{~L} 8 \mathrm{D}$ の明暗周期から消灯・点灯のタイミングを 2 時間ずらして 暗期における雄の反応性を調べたところ，いずれの場合も消灯後 2 時間に反応性は最大レベルに達し，以後暗期終了まで維持され
た。実験した範囲内では, 性フェロモンに対する反応性の増加に は，消灯の刺激が重要であることが示された。

ケナガカブリダニはリンゴ樹上で越冬しているか 舟山 健（秋田農技セ果試）

リンゴ園でケナガカブリダニはナミハダニの重要な天敵である が，その越冬場所は確認されていない。そこで，本種がリンゴ樹 上で越冬しているかどうかを 2007 年 4 月から 2008 年 3 月に秋田 県で調査した。リンゴ葉上で本種雌成虫は, ナミハダニが急増し た 9 月に増加し，11月上旬まで観察されたが，11月上旬にカブリ ダ二類の卵は観察されなくなった。1 12 月上旬にリンゴ樹の粗皮下 を観察したところ，ナミハダニ休眠雌成虫と共に本種の雌成虫が 見出された。本種の越冬個体数は, ナミハダニ休眠雌の多い粗皮 が少ない粗皮よりも有意に多く，翌年 3 月上旬は，前年 12 月上旬 よりも有意に少なかった． 5 月から 10 月までリンゴ樹上に取り付 けた Phyto Trapに，本種は 9 月まで捕獲されなかったが，10月に はナミハダニ休眠雌成虫と共に多数の雌成虫が捕獲された。

RT-PCR 法を用いたセイヨウミッバチ Apis mellifera のイス ラエル急性麻痺ウイルスおよびカシミールハチウイルスの 検出：ヨルダンにおける初めての検出例 Amal A. ALAbBadi $^{1}$ • Dhia S. Hassawi ${ }^{2}$ - Saida A. Abu-Mallouh ${ }^{2}$. Mohammad S. Al-MAZRA'WI ${ }^{1}\left({ }^{1}\right.$ Department of Plant Production and Protection, ${ }^{2}$ Department of Biotechnology, Faculty of Agricultural Technology, Al-Balqa' Applied University, ヨル ダン ) …............................................ 183

蜂がウイルス感染しているかどうかの診断に PCR 法を用いるこ とは, 目視主体による従来の感染診断法の問題点を克服する大変 有効な方法であることを示した。ヨルダン全域の 10 地域の蜂群か ら，PT-PCR 法を用いてイスラエル急性麻痺ウイルス（IAPV）打 よびカシミールハチウイルス（KBV）の発生を調査した。蜂群は, 蜂数の減少, 急激な崩壊, 麻痺, 褐変といった症状を呈していた。 上記二種のウイルスは，採集したサンプルのいくつかから同定さ れた。 IAPVは $13 \%, \mathrm{KBV}$ は $12 \%$ のサンプルから検出された。 IAPV と KBV は, 調査地域によって異なる地理的分布を示した。 RT-PCR 産物は，IAPVで 470-473 塩基対，KBVで 408-409 塩基 対であった。塩基配列を解析した結果，IAPV は KBVに最も近縁 であった。

韓国済州島のウンシュウミカン園におけるミヤコカブリダ ニ（ダニ目：カブリダニ科）の越冬場所川島充博. Chuleui JUNG（安東大，韓国）…………............ 191 ミヤコカブリダニ（以下ミヤコ）を利用した生物的防除技術打 よび野外におけるミヤコの越冬状況調査法を改善することを目的 とし，2008 年 2 月に, 韓国済州島の 2 つのウンシュウミカン園に おいてミヤコの越冬場所を調べた。採集されたミヤコはほとんど が雌成虫であり，雄成虫打よび幼若虫はごくわずかであった。 ヤコは主に下草上から採集され，ミカン樹上や園周辺の防風樹か らの採集数は少なかった。下草種間でミヤコの密度を比較したと 
ころ，ロゼットを形成する下草種に打いて，ロゼットを形成しな い種よりも，常にミヤコの密度が高い傾向がみられた。これらの 結果から， ロゼットを形成する下草は，園内でミヤコを保護する 上で有効な越冬場所となっている可能性が示された。 また，この ような地表付近の生息場所は, 野外に打けるミヤコの越冬状況を 調べるのに有効な場所であると考えられた。

\section{ニッポンクサカゲロウとヤマトクサカゲロウのワタアブラ} ムシに対する機能の反応 Andres Felipe MONTOYAALVAREZ $^{1}$ - 伊藤 桂 ${ }^{1,2}$ - 中平賢吾 ${ }^{1}$ - 荒川 良 ${ }^{1}\left({ }^{1}\right.$ 高知 大農， ${ }^{2}$ 科学技術振興機構サテライト高知) ……....... 201

日本土着のニッポンクサカゲロウと輸入種であるヤマトクサカ ゲロウ両種の幼虫にワタアブラムシ 2 4 齢幼虫を異なる密度で与 えて, 12 時間と 24 時間の捕食量を求め, 機能の反応を調べた. その結果両種とも餌密度と捕食量の関係は Holling のタイプ II の 反応を示した。推定最大捕食数はヤマトクサカゲロウがニッポン

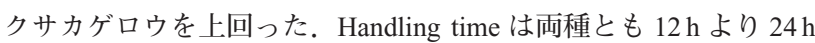
で減少したが，ニッポンクサカゲロウでの值の方がヤマトクサカ ゲロウより高くなった. Attack coefficient はニッポンクサカゲロウ の 2 齢と 3 齢の值がヤマトクサカゲロウより大きくなった。これ らの結果はアブラムシ密度が高い時，より多くのアブラムシを捕 食することを示している。しかし，日本に扔いては，ニッポンク サカゲロウが将来の生物的防除資材として市販される可能性を秘 めている。それは，環境への影響という点で，ニッポンクサカゲ ロウが土着種であり, 非標的効果を考慮する必要のないことが, ヤマトクサカゲロウより重要になるからである.

黒色背景付き円形黄色粘着トラップはミカンキイロアザミ ウマの誘引カが強い Bishwo Prasad MaINALI • Un Taek LIM（国立安東大学, 韓国) 207

正方形の黄色平板粘着トラップを基準とし，同じ素材で作製し た円形，半円形，菱形，三角形そして逆三角形のトラップを用い ミカンキイロアザミウマに対する誘引力を実験室内で比較すると， 円形の黄色平板粘着トラップの誘引力が最も強かった。 円形の黄 色平板粘着トラップに黒色, 黄色, 緑扔よび青色の背景を付けて 誘引力を比較すると, 背景が黒色のトラップに最も多数のミカン キイロアザミゥマが誘引された，黒色の背景 $(12 \mathrm{~cm} \times 12 \mathrm{~cm})$ に円 形の黄色平板粘着トラップ（直径 $5 \mathrm{~cm}$ ) を付けた改良型トラップ を作製し，イチゴを栽培した温室内で市販の黄色平板粘着トラッ プ（幅 $5 \mathrm{~cm} \times$ 長さ $8 \mathrm{~cm}$ ） と比較すると, 市販のトラップの $2.3 \sim 21$ 倍多くミカンキイロアザミウマを誘引した。このように，この改
良型トラップはアザミウマ管理に有効な新たな手法となるであろ う.

捕食寄生者サビマダラオオホソカタムシ（鞘翅目：ムキヒ ゲホソカタムシ科）の寄生成功率と適応度に寄主ステージ と寄生個体数が与える効果 浦野忠久 (森林総研) ‥ 215 サビマダラオオホソカタムシに打ける適応度要素（羽化成虫数 と生重）と寄生成功率（寄主死亡率）を, 寄主であるマツノマダ ラカミキリの 3 つの発育ステージ（幼虫, 蛹打よび成虫）間で比 較した。異なる数のホソカタムシ 1 齢幼虫を寄主個体上に接種し た結果，寄主蛹では 1 個体の接種で $88 \%$ の寄主が死亡したのに対 し，幼虫打よび成虫の死亡率は $50 \%$ 以下であった。寄主 1 個体当 たりの羽化個体数, 羽化成虫の生重拈よび産卵小管数の推定值の いずれも寄主蛹で最大となった。以上の結果から蛹が寄主として 最も質の高いステージであることが明らかになった。蛹は他のス テージに比べて不活発なため寄生を受けやすく, また蛹に寄生し た場合の適応度が高くなるのは，寄主摂食速度が速いためと考え られた。 1 個体の寄主蛹に対し 1 齢幼虫 2 個体を接種することに よって, 次世代羽化成虫の個体レベルの適応度が最大になるもの と推定された。

植物共生糸状菌 Neotyphodium lolii のペレニアルライグラ スへの感染がアワノメイガおよびイネヨトウの㩒食や生存 に及ぼす阻害的効果 柴 卓也・菅原幸哉（畜産草地研）

225

麦角菌科・ Neotyphodium 属の植物共生糸状菌（ネオティフォ ディウムエンドファイト) はイネ科植物の体内に共生し，宿主と なる植物の害虫抵抗性や環境ストレス耐性を向上させる例が知ら れており，生物防除や植物の生育促進に役立つ微生物として注目 されている. そこで, Neotyphodium 属菌の一種, N. lolii が感染し たペレニアルライグラス (Lolium perenne) を用いて, N. lolii の感 染がアワノメイガ（Ostrinia furnacalis）幼虫扎よびイネヨトウ (Sesamia inferens) 幼虫の摂食や生存に及ぼす影響について調査し た.アワノメイガ幼虫は N. lolii が感染した葉よりも非感染葉を好 んで摂食し，感染葉のみを攖食させた場合は，絶食させた場合に 近い生存曲線を示し，6日以内に全ての幼虫が死亡した。イネヨ トウを用いた試験に打いても同様の結果となった。こうした結果 から， N. lolii の感染により，ペレニアルライグラスにアワノメイ ガおよびイネヨトウの䀧食や生存に影響を及ぼす何らかの要因が 生じていることが示唆された。 